\title{
FACTORS AFFECTING MOTIVATION OF ENGLISH-MAJORED STUDENTS TOWARDS LEARNING ENGLISH AT A UNIVERSITY IN THE MEKONG DELTA, VIETNAM
}

\author{
Thi Bao Dung Dang, \\ Van Lanh Le', \\ Tuong Vy Ha \\ Faculty of Linguistics and Literature, \\ Tay Do University, \\ Can Tho City, Vietnam
}

\begin{abstract}
:
It could be broadly accepted that motivation plays its fundamental role as one of the most important elements in foreign language learning. The present research investigated factors affecting motivation in learning English of freshmen at Tay Do University. The participants were 84 freshmen studying in Faculty of Linguistics and Literature. In the study process, these participants were given questionnaires which consisted of several statements related to the mentioned factors and the interview to get information. The collected data from the two instruments mentioned above were all analyzed afterward. The current study showed that there were elements that motivate freshmen towards English learning. Parental, environmental, teacher's and intrinsic (personal) factors were examined. It is hoped that this research can be helpful for not only students but also teachers in learning and teaching English.
\end{abstract}

Keywords: motivation of English-majored students; foreign language learning; learning English

\section{Introduction}

As we know so far, English is one of the most commonly used languages in the world. Indeed, living in a very connected world requires more communication skills and as a bridge, it is trouble-free for you to connect with people, movies, music, culture, or whatever you want via English fluency. English language plays a vital role in our lives because it makes possible communication between different countries and not only that, it is also a common language appearing in a variety of aspects such as trading, diplomacy, education, economy, society, and international business in general.

i Correspondence: email lvlanh@tdu.edu.vn 
For that reason, in the fierce competition of globalization and modernization, more and more recruiters and multinational firms are demanding candidates with their advantage of using English fluently. It is improved one thing that people who have wellbuilt English ability can obtain greater opportunities than the others in a job interview. For better equipment, almost all universities and colleges teach English as a compulsory subject for a graduation requirement. However, acquiring a foreign language is not really easy. Hence, we have to identify the crucial purpose of learning English or in other words, creating motivation is an undeniable element that can help us conquer English proficiency.

In recent years, the determination of motive learning and the relationship between motivation and learning outcomes has been drawing many researchers' attention because it is likely a "gold key" helping educationalists to approach and explore learners' potential competencies. The learner's motivation decides the result and effectiveness of educational activities. And put another way, motivation plays a vital role in orienting and encouraging study operation. There are some subjective factors affecting directly motivation, in most cases, they could be the self-belief, interests in career, responsibility, self-control.

Nevertheless, it would be a challenging task for students when English is more likely a foreign language with lots of differences in comparison with Vietnamese, result in demotivating and getting lost which is a worrying matter in motive determination. Furthermore, it is undisputed that there is always intense desire of all students for possessing a good English fluency. Motivation, thus, will be a prerequisite element for students in adjusting attitude in order to exert themselves conquering English.

Motivation is the reason telling us evidently why a student decides to learn an ology, it is also a key showing how hard a student invest in their subjects because of its influences toward learning. There would be, of course, not an exception for all English majored freshmen at Tay Do University in processing of choosing a major, especially English linguistics.

Accordingly, those indicated reasons above have been strong motivation to speed up the researcher in conducting the study named "Factors affecting motivation of English -majored students towards learning English at a University in the Mekong Delta".

\section{Research aim}

The aim of this study was to find out the factors affecting motivation of English - majored freshmen towards learning English at Tay Do University.

\subsection{Research question}

This study was conducted to answer the following research question:

- What are the factors affecting motivation of English-majored freshmen towards learning English at Tay Do University? 


\section{Literature review}

\subsection{Definitions of motivation}

As mentioned in Chapter 1, motivation could have been considered as one of outstanding terms in the process of linguistic researching because of its effects towards learning result. For this reason, a huge amount of research papers has been conducted and brought about that is mindsets and definitions of motivation, some of which were mentioned below.

First of all, the term motivation is simply understood that is something encourages you to act. A definition excerpted from Cambridge Dictionary mentioned that "motivation is the need or reason for doing something". More clearly, Boundless Psychology showed that "Motivation describes the wants or needs that direct behavior toward a goal. It is an urge to behave or act in a way that will satisfy certain conditions, such as wishes, desires, or goals". S. Sibanda briefly defined "Motivation is the invisible hand that controls all the activities of humans and organisms" in 2015.

National Research Council (2001) wrote that "Motivation is a condition that activates and sustains behavior toward a goal. It is critical to learning and achievement across the life span in both informal settings and formal learning environments". For example, children who are motivated tend to be engaged, persist longer, have better learning outcomes, and perform better than other children on standardized achievement tests (Pintrich, 2003).

In fact, it cannot be that motivation contributes effectively and plays a vital role in learning English. Alizadeh (2016) stated "Motivation has a very important role in learning English as a foreign or second language successfully". Besides, Nuridin (2019) also agreed that "It is undeniable that motivation plays a key role in second or foreign language learning". Motivation makes the learning results better, they interact with each other. For this reason, "That there exist significant correlations between motivation and foreign language learning" was the results showed in the research of Bernaus (1995).

Due to the lack of enough motivation, some difficulties may happen for learners. Without desire to learn, it is very difficult for learners to gain effective learning. As Huitt (2001) thought that paying attention to the importance of language will help learners improve their motivation to learn even if they do not have enough intrinsic motivation. It can be stated that teachers should be aware of significance of motivation in learners' language learning and through some changes they can help learners increase their motivation.

In short, motivation is one of the most important factors which influence language learners' success or failure in learning a language.

\subsection{The importance of motivation}

Human beings, throughout a long length of historical periods, have made an attempt to take advantages of various methods of communication for the purpose of getting knowledge from other nations to preserve them for the next generations. Needless to say, a language is like an efficient tool in communication. 
English, knowing it is really important because of their population in communication nowadays. However, to be better and better when we study this subject, motivation is a really significant element in the first step.

First of all, "motivation" is like a crucial element that cannot be replaced in life. Motivation is the reason before doing an action. Schmitz (2012) believed "Motivation is what makes us do the things we do". Any actions need it to be completed and become more successful. Therefore, Emily R. Lai (2011) stated "Motivation refers to reasons that underlie behavior that is characterized by willingness and volition". Zampas (2014) said "Without motivation in life, it's hard to strive for success and achieve internal happiness".

In learning English, Guthrie (1997), said that intrinsic motivation is a significant impact not only on reading comprehension but on the other aspects of reading such as reading breadth. According to Moskovsy and Alrabai (2009), instrumental motivation plays more important role. Similarly, "It is important to think about motivation as the essence of language teaching because of the stark realities of learning English for most of our students" was considered by Anjomshoa and Sadighi (2015).

In general, there is no doubt about the importance of "motivation" in learning English.

\subsection{Demotivation}

Demotivation is the mindset that students in schools are losing their motivation to learn English as time goes by. Demotivation can be described as a decrease or drop in level of motivation (Bekleyen, 2012). If students cannot get their motivation, it easily becomes demotivation and in fact, the number of demotivated learners is increasing. Therefore, while motivation is a positive side in promoting English learning, demotivation is the opposite.

Demotivation can be regarded as the negative counterpart of motivation. Likewise, demotives can be considered as the negative counterparts of motives. Moreover, a demotivated learner is someone who gets lost his interest for some reasons. The loss of interest can originate from different sources of demotivation. For instance, an unprepared teacher or an uninteresting textbook can act as a demotivation for students. However, not all researchers agree that demotivation is only external. Many researchers (e.g., Arai, 2004, Falout \& Maruyama, 2004 and Sakai \& Kikuchi, 2009) go on to expand Dörnyei's original definition to cover both external and internal factors (i.e., demotivators) which reduce or diminish the motivation to study English.

Like motivated factors, demotivation can conclude internal and external factors such as learning environments, teacher's components, parental factors, social factors. 'Lack of school facilities','overemphasis on grammar', 'long passages' and 'expectancy to use grammatically correct English in the classroom' as strong sources of demotivation (Meshkat and Meskani, 2012). Since the students are not required to use English language in their future studies, this long and tedious process of learning a language make them feel tired. Their other courses related to their main fields of study also cause 
demotivation. Therefore, getting awareness of demotivation is able to help students minimize its influences.

If students can shed light on factors that make them demotivated and fix them, certainly, their learning results will be better and better. Even though, its crucial role in the learning process has been confirmed (Dörnyei and Ushioda, op.cit.).

\subsection{Factors affecting motivation in learning English}

There are two types of motivation: intrinsic motivation, or internal factors that motivate a person to learn. Then, there is extrinsic motivation, or external factors that engage the person in the process of learning English. Both types of motivation are important in learning English.

Ryan and Deci (2000) posit their accepted distinction of motivation between "intrinsic" and "extrinsic" motivation. As in the classification, intrinsic motivation is an activity for its innate gratification without the thought of any consequence, while extrinsic motivation is understood like an activity in order to receive external rewards.

In the last few years, the topic of intrinsic and extrinsic motivation has raised a lot of interest in EFL learning (Oletić, 2014).Similarity, Nina (2014) also stated that "intrinsic or extrinsic motivation and the correlation between motivation and success in learning a foreign language have been examined".

Extrinsic motivation helps students become driven and competitive, while intrinsic motivation supports seeking knowledge for its own sake. Ultimately, fostering both types of motivation help students develop good study habits and an investment in learning. These factors are explained in the following section.

\subsection{Intrinsic factors}

As mentioned above, motivation is generated by two main factors and intrinsic factor is one of them. Intrinsic motivation is a motivation in learning that is from an internal force such as the desire for more personal development in general or interests. Intrinsic motivations include personal interest in learning English and personal need to achieve a goal, such as a dream job and great opportunities.

There are a huge amount of mindsets about intrinsic factors that motivate students in learning mentioned by many researchers. Garner (1985) stated that intrinsic motivation was as the extent to which the individual works or strives to learn the language because of a desire to do so and the satisfaction experienced in this activity. According to Kendra (2019), "Intrinsic motivation refers to behavior that is driven by internal rewards. In other words, the motivation to engage in a behavior arises from within the individual because it is naturally satisfying to you". Intrinsic motivation is characteristic in the activities we perform for pure enjoyment or satisfaction. Indeed, Chiew Fen Ng and Poh Kiat Ng (2015) agreed in a same way that intrinsic motivation is the enjoyment of learning a second language for its own sake without any external pressure. For intrinsically motivated students, engaging in a learning task is an end all to itself, so they learn for reasons such as mastery, challenge, curiosity, and enjoyment or in other saying, students who are intrinsically 
motivated read for assignments, but also do so because they enjoy it and want to gain mastery of a subject.

Lucas and his colleagues (2010) investigated a study focusing on intrinsic motivation factors of 240 college freshmen within Metro Manila, Philippines. Results showed that freshmen are intrinsically motivated to learn English speaking skills via accomplishment and knowledge. This research also indicated that "students are intrinsically motivated to learn certain communicative skills depending on what type of intrinsic motivation they more or less use" (Lucas et al., 2010, p.16).

In conclusion, intrinsic motivation is an important topic in education. Certain studies carried out in the 1970s and 1980s showed that rewards can lead to a decrease in intrinsic motivation among people who are already doing something because of their own reasons (Brophy, 2004). Intrinsic elements can be from short-term goals (good grades, prizes from the teacher and parents, participation in competitions, etc.) to longterm ones (possibility of winning scholarships, better job opportunities, higher social status, etc). Unlike extrinsically motivated behavior, it is freely chosen (Deci, \& Ryan, 1985).

\subsection{Extrinsic factors}

Extrinsic motivation is an important part of dichotomy of motivation (Ryan and Deci, 2000). Extrinsic motivation refers to behavior that is driven by external rewards such as money, fame, grades, and praise. This type of motivation arises from outside the individual, as opposed to intrinsic motivation, which originates inside of the individual. An individual is extrinsically motivated when the goals of actions undertaken go beyond those inherent in the activity itself. Therefore, these are activities an individual engages to an expected outcome rather than for one's sake (Vallerand et al, 1992). While intrinsic motivation involves doing something because it is personally rewarding to you, extrinsic motivation involves doing something because you want to earn a reward or avoid punishment. On the other hand, those who are extrinsically motivated perform a certain action not because they truly enjoy it, but because of a reward that is available in their environment (Topalov, 2011).

In learning, it is understood that extrinsic motivation is characterized by factors that are external to the self. The student is motivated to learn or achieve not by personal interest or desire for growth, but from a desire to please others by meeting expectations set by parents, teachers and learning environments.

Extrinsic motivators include parental expectations, expectations of other trusted role models, earning potential of a course of study, and grades as well. If students are not self-motivated, it can be denied that extrinsic elements of learning motivation really affect their leaning and play a crucial role to help them in getting interests.

\subsection{Learning environment}

According to The Glossary of Educational Reform (2014), learning environment refers to the diverse physical locations, contexts, and cultures in which students learn. 
It could be said that it is one of the factors that can motivate students in the process of studying. Ekiz (2016) agreed that "Apart from parental and student-related factors, classroom features or environmental factors also affect students' motivation". An enjoyable and supportive classroom atmosphere will create motivation for studying better. With the same thought, Dorman, Aldridge, \& Fraser, 2006 agreed that students learn better when they view the learning environment as positive and supportive. A positive environment is one in which students feel a sense of belonging, trust others, and feel encouraged to tackle challenges, take risks, and ask questions (Bucholz \& Sheffler, 2009). It also encourages student to express their ideas and thinking comfortably. Such an environment provides relevant content, clear learning goals and feedback, opportunities to build social skills, and strategies to help students succeed (Weimer, 2009). Environmental factors really affect learners' motivation in learning.

In contrast, if the classroom is too crowded and there is not enough light, it demotivates students, because it creates difficulty in studying due to troublesome conditions (Trong Tuan, 2012). Mac Intyre (1999) and Young (1999) strongly believed that students' anxiety created by a tense classroom climate was one of the most potent factors that undermined learning effectiveness and L2 motivation. From this viewpoint, it is uncomplicated to be proven one thing that if the learning atmosphere is not conducive to gain new knowledge or skills, it will be hard for learners to remain their interests.

In conclusion, by making an advantageous environment with purposeful rules, students feel motivated to do the right thing and help one another.

\subsection{Teacher's components}

Teachers play a pivotal role in promoting motivational qualities to their learners. Because of the importance of the nature of the interactions that occur between learners and teachers, many studies have been dedicated to the discussions of the influence of teachers in the process of foreign language learning. Wong (2015) found that there is a positive correlation and direct relationship between the teacher and a students' English attainment.

Dornyei (2001) mentioned some teacher's factors affecting students' motivation such as appropriate teacher behavior, teacher's enthusiasm and a good relationship with the students. When teachers help the learners to develop an internal sense of control as well as feelings of effectiveness in their ability to carry out tasks, then there are great chances for the learners to become motivated to learn (C. Fen Ng and P. Kiat Ng, 2015). Besides, the teacher's attitude is also a great element affecting students because teacher enthusiasm served as a positive external catalyst facilitating student interest, and curiosity to learn (Qin Zhang, 2014). In what showed, what keeps students motivated is a motivated teacher.

Nextly, Good and Brophy (1994) showed their ideas that 'The teacher should be a patient, encouraging person who supports students' learning efforts. Students should feel comfortable taking intellectual risks because they know that they will not be embarrassed or criticized if they make a mistake. 
Moreover, teachers and their teaching methods also affect students' motivation. An interesting class is easier to draw students' attention. According to Bayraktar's research (2015), in order to create an effective teaching and learning atmosphere in a classroom, it has been achieved that teacher's effective use of methods, techniques, tools and materials in relevant teaching field has an important effect on student motivation. Mendes (2003) also said that an effective classroom environment, which enhances the motivation of the students, should be sufficient for the teaching methods and techniques of the educators. By using exciting and unique teaching techniques during training, the trainers better adapt the students to the lesson, which enables them to get the motivation for success (Bolkan and Goodboy, 2010).

Therefore, teachers should vary the activities, tasks and materials because students are reassumed by the existence of classroom routines that they can depend on. Thus, varying the activities, tasks and materials can help to avoid demotivation and increase students' interest level (Trong Tuan, op. cit.).

To sum up, some students can be self-motivated due to a natural love of learning. But even with the students who do not have this thing, a great teacher will make learning become fun and help them to reach their full potential.

\subsection{Parental factors}

Family is the roof affecting directly to human for all aspects in life. Garrett (1995) asserts in a speech at the Oklahoma Administrator's Conference that "the smallest school in America is the family", which illustrates the significant role that family has in education and motivation of students. It is, hence, quite reasonable to say that parental factor is one of things motivating children because parents are the first teachers of a student, and they take responsibility for their education. "Parents had substantial but varying influences on their children's motivation" (Yuko, 2014), that is because it depends on background and children's level.

Butler (2014) wrote in his research that "Parents, as a noteworthy social-relevant element impacting kids' inspiration and the accomplishment, have gotten considerable consideration in general education". Parents' participation in the education process significantly affects the motivation and academic achievement of the learner (Fan \& Chen, 2001). Eccles and Harold (1993) found that "Parents tend to play a decisive role in the motivational development of children and adolescents and shape children's early achievementrelated orientations and perceptions". Because parental encouragement is a positive source of motivation which supports for students' beliefs.

However, the impact of parents can be light and dark side to students. C. Daniel (2018) and his partners strongly believed that a positive active role would involve parents monitoring their child's progress in language learning, showing interest, and encouraging success, and a negative active role would involve a range of discouraging behaviors, from openly belittling the importance of learning a second language to favoring other areas of learning over languages. The passive role concerns parents' attitudes to the second-language community. 
To sum up, parental encouragement is perceived to play the most significant role during the development of motivational intensity, desire to learn English, and attitude toward learning English.

\subsection{Related studies}

In 2016, two researchers Seda Ekiz và Zahitjan Kulmetov conducted a study to find out "The Factors Affecting Learners Motivation in English Language Education". It was investigated to deeply understand about the role of motivation and factors affecting students' motivation in learning English like a foreign language as well. The two methods used were qualitative and quantitative with a survey on 40 freshmen, English pedagogy department in Uludağ University (Turkey). The collected result showed that parents, teachers' attitude and class' environment were three elements taking the highest rate. It was obvious that learners felt more motivated in learning when they got the enthusiastic support from their parents. Moreover, getting a chance to study with active classmates made them feel more exciting, too.

Next, the study "Factors affecting motivation in learning language" was carried out by a PhD team in Malaysia Technology in 2017 with the aim of finding out elements which really influenced on learning motivation. The tool used was questionnaire and it was given to 80 participants in Ekolah Menengah Kebangsaan Lepar Utara (the west coast of Malaysia), almost students there learned English as a second language. Due to the strong attempt, researchers pointed out 3 crucial factors causing learning motivation in English. They included parental factors, teachers' influences and students' attitude towards their studying. Specifically, teacher was the element that took the greatest percentage of questionnaire.

Another research of Naw Sant is "A study on factors affecting students' motivations in the English language classrooms" in 2018, which indicated that the attraction in teaching methods, teacher's manner, interesting tasks could bring students a great motivation. In his conclusion, the researcher said that motivation played a key role in English classes because it made students be more flexible and active when they got assignments. His questionnaire was given for 120 students in Maija Yang University, Myanmar and then it was analyzed with explanatory sequential mixed method.

For all above evidence, it was seen that self - interests, learning environments, teacher's environment, parental factors and social factors were factors completely affecting students' motivation. There were various studies finding out motivated factors towards English learners. However, no study investigated on the factors affecting motivation in learning English of English- majored freshmen at Tay Do University had been conducted. 


\section{Research methodology}

\subsection{Research design}

In order to answer the research question, this survey research was carried out at Tay Do University. Therefore, the participants were English-majored freshmen at Tay Do University. The instrument used to get information of the participants were the questionnaire and the interview. And then, the collected data of these two instruments were analyzed to show "the factors affecting motivation in learning English" of Englishmajored freshman at Tay Do University. Besides, students' report was concluded to give more information about this. This is a combination of quantitative and qualitative research.

\subsection{Research participants}

This research was conducted on 84 freshmen majoring in English course 14 (2019-2023) at Tay Do University. They were males and females from 18 to 21 years old. They speak Vietnamese as their mother tongue and English is considered as their foreign language. They were given questionnaires and interview in order to get information about the aspects. This helped to provide the evidence that made this research more reliable and found out "the factors affecting motivation in learning English" of English- majored freshman at Tay Do University

\subsection{Instruments}

Questionnaire was a helpful instrument in this research. The reason why the researcher used the questionnaire was that it provided a reasonably cheap, quick, and an efficient way obtaining large amounts of information from a large sample of people.

\section{Findings}

The questionnaires helped the researcher to get a lot of valuable and reliable information from participants. This section was unbelievably significant to the research since it was conducted in an effort to get more insights into factors affecting students' motivation in learning English. This section was categorized into 4 small parts, corresponding to 4 prevalent elements stated in chapter 2 that motivated the participants from intrinsic factor and three of extrinsic elements, namely, teacher's components, learning environments and parental factors as well. 


\subsection{Intrinsic factors of motivation}

Table 1: Intrinsic factors of motivation

\begin{tabular}{|l|c|c|c|c|c|}
\hline $\begin{array}{l}\text { You are motivated in learning } \\
\text { English because... }\end{array}$ & $\begin{array}{c}\text { Strongly } \\
\text { agree }\end{array}$ & Agree & Neutral & Disagree & $\begin{array}{c}\text { Strongly } \\
\text { Disagree }\end{array}$ \\
\hline $\begin{array}{l}\text { 6. You are interested in learning } \\
\text { English. }\end{array}$ & $41.67 \%$ & $48.8 \%$ & $3.57 \%$ & $5.96 \%$ & $0 \%$ \\
\hline $\begin{array}{l}\text { 7. You would like to travel to } \\
\text { many places around the world. }\end{array}$ & $44.05 \%$ & $46.43 \%$ & $7.14 \%$ & $0 \%$ & $2.38 \%$ \\
\hline $\begin{array}{l}\text { 8. Your dream job requires good } \\
\text { English competence. }\end{array}$ & $39.29 \%$ & $48.81 \%$ & $11.9 \%$ & $0 \%$ & $0 \%$ \\
\hline $\begin{array}{l}\text { 9. You realize the importance of } \\
\text { using English fluently for your } \\
\text { long-term goal in the future. }\end{array}$ & $42.86 \%$ & $44.05 \%$ & $11.9 \%$ & $1.19 \%$ & $0 \%$ \\
\hline $\begin{array}{l}\text { 10. Being good at English makes } \\
\text { you proud of yourself. }\end{array}$ & $23.81 \%$ & $47.62 \%$ & $25 \%$ & $2.38 \%$ & $1.19 \%$ \\
\hline $\begin{array}{l}\text { 11. You want to approach your } \\
\text { favorite English products without } \\
\text { Vietsub (film, music, news, etc). }\end{array}$ & $35.72 \%$ & $51.19 \%$ & $9.52 \%$ & $1.19 \%$ & $2.38 \%$ \\
\hline
\end{tabular}

As illustrated above, Table 1 embraced 6 statements in total that indicated the respondents' first intrinsic factors.

To begin with, let's take a close look for statement 6 . Over $90 \%$ of students consisting of $41.67 \%$ (35/84) strongly agreed and $48.8 \%$ (41/84) agreed with the statement. The residual with $3.57 \%$ (3/84) had no idea, $5.96 \%$ (/84) gave disagreement and no one chose strong disagreement. Hence, it came to the conclusion that English majored freshmen were motivated in learning English due to their interests.

Moving to statement 7 , there were $2.38 \%$ of participants (2/84) strongly disapproving the idea that students felt motivated to learn English because they would like to travel to many places around the world. Next, in succession, there were $44.05 \%$ of students (37/84) strongly agreeing, 46,43\% (39/84) agreeing while 6 remainders (7.14\%) did not take any side. For statement 8 's result, 33 participants $(39.29 \%)$ totally approved, $48.81 \%$ (41/84) of students gave approval and $11.9 \%$, equivalent to 10 respondents showed hesitation. No one gave disagreement or strong disagreement. These two statements reflected the fact that traveling and getting dream job became attractive goals to motivate students. These made them have more dynamic and study English better.

In statement 9 , more than $60 \%$ of students $(42.86 \%(36 / 84)$ and $44.05 \%(37 / 84)$ combined) successively showed strong acceptance and assent to the opinion that realization about the importance of using English fluently for a long-term goal in the future cause for their motivation. The remainders $11.9 \%(10 / 84)$ were caught in the middle. Still, there was 1 student (1.19\%) giving objection.

Besides, only 1 student (1.19\%) in statement 10 showed strong disagreement, $2.38 \%$ of students (2/84) with disapproval and $25 \%(21 / 84)$ in total having no comment on this statement. In contrast, the majority of freshmen $(23.81 \%(20 / 84)$ "strongly agree" and 
47.62\% (40/84) "agree") affirmed that that they were motivated due to pride of being good at English.

Lastly, in statement 11, the proportion of participants expressing strong agreement with their favorite English products making dynamic was 35.72\% (30/84), followed by $51.19 \%(43 / 84)$ of students agreeing with the statement. Nevertheless, 8 out of 84 participants (9.52\%) were in neutral state and only 3 students gave disagreement (1.19\%) and strong disagreement $(2.39 \%)$.

As a whole, from these 6 statements' findings, it could be inferred that most of the students had motivation for learning English because of intrinsic factors. They embraced interests, traveling to many places around the world, dream jobs with required good English competence, the importance of using English fluently for the long-term goal in the future, the pride of being good at English and the ability to approach English products without Vietsub.

\subsection{Extrinsic factors regarding learning environment}

Table 2: Extrinsic factors regarding learning environment

\begin{tabular}{|l|c|c|c|c|c|}
\hline $\begin{array}{l}\text { You feel more motivated } \\
\text { in an English class when... }\end{array}$ & $\begin{array}{c}\text { Strongly } \\
\text { agree }\end{array}$ & Agree & Neutral & Disagree & $\begin{array}{c}\text { Strongly } \\
\text { disagree }\end{array}$ \\
\hline $\begin{array}{l}\text { 12. You have a chance to study } \\
\text { with many active friends. }\end{array}$ & $22.62 \%$ & $54.76 \%$ & $20.24 \%$ & $2.38 \%$ & $0 \%$ \\
\hline $\begin{array}{l}\text { 13. The learning atmosphere makes } \\
\text { it comfortable for you. }\end{array}$ & $20.24 \%$ & $55.95 \%$ & $16.67 \%$ & $5.95 \%$ & $1.19 \%$ \\
\hline $\begin{array}{l}\text { 14. You are able to be free to show } \\
\text { your ideas that contribute to the } \\
\text { lesson. }\end{array}$ & $14.29 \%$ & $53.57 \%$ & $28.57 \%$ & $1.19 \%$ & $2.38 \%$ \\
\hline $\begin{array}{l}15 . \text { Your classroom has suitable } \\
\text { brightness and high-quality } \\
\text { equipment. }\end{array}$ & $14.29 \%$ & $44.04 \%$ & $38.01 \%$ & $3.57 \%$ & $0 \%$ \\
\hline $\begin{array}{l}\text { 16. Your workgroup vibrantly } \\
\text { discusses a topic together. }\end{array}$ & $19.04 \%$ & $38.01 \%$ & $38.01 \%$ & $3.57 \%$ & $1.19 \%$ \\
\hline
\end{tabular}

Table 2 including 5 statements went on elaborating students' dynamic elements with learning environment. Starting with statement 12, 19 out of 84 participants (22.62\%) strongly agreed and 46 others (54.76\%) approved that having a chance to study with many active friends made them feel more motivated in an English class. The residual consisted of $20.24 \%$ (17/84) hesitations and particularly 2 students showing disagreement $(2.38 \%)$.

For statement 13, only 5 students (5.95\%) with strong dissent and 1,19\% (1/84) gave objection because a comfortable learning' atmosphere did not give motivation for them. Conversely, $76.19 \%$ was the combined percentage in which $20.24 \%$ (17/84) participants completely consented and 55.95\% (45/84) showed agreement with the statement. This meant a huge of participants agreed that they were motivated because they got to learn 
in an English class with relaxing atmosphere. And the rest of students $14 / 84(16.67 \%)$ had no idea about this statement.

Moving on to statement 14 and 15, it was a coincidence when the majority of respondents $14.29 \%(12 / 84)$ in these two sentences strongly agreed. In statement 14, there was only one participant $(1.19 \%)$ and 2 participants $(2.38 \%)$ disapproving and strongly disapproving with the supposition that "You are able to be free to show your ideas that contribute to the lesson", respectively. Nonetheless, 53.57\% (45/84) agreed with this statement. Down to statement 15, just more than 5\%, successively 3.57\% (3/84) and 1.19\% $(1 / 84)$ of students entirely dissented and strongly assented that sentences beginning with "it has the suitable brightness and high-quality equipment" were motivational factor of learning environment. At the same time, $9.09 \%$ of freshmen $(5 / 55)$ gave agreement.

For the last statement in the table (numbered 16), when asking the participants about the idea "You feel more motivated in an English class when your workgroup vibrantly discuss a topic together", the researcher came to know that once again, over $50 \%$ of his classmates consented to the supposition mentioned above (the combination of $19.04 \%$ (16/84) strong agreements and 38.1\% (32/84) agreements). Meanwhile, there were $38.1 \%$ of participants (32/54) who showed hesitation and 4 respondents, in which $3.57 \%$ (3/84) and only one of them (1.19\%) did not agree and strongly disagree, alternately.

All in all, it could be implied that learning environment was one of the main factor of students' motivation. Specifically, a learning environment that students had active friends to study with, an enjoyable atmosphere and freedom. These were extremely ideal for freshmen to show off their abilities as well as possible.

\subsection{Extrinsic motivation concerning teacher components}

Table 3: Extrinsic motivation concerning teacher components

\begin{tabular}{|l|c|c|c|c|c|}
\hline $\begin{array}{l}\text { A teacher gives you more } \\
\text { motivation studying English } \\
\text { since... }\end{array}$ & $\begin{array}{c}\text { Strongly } \\
\text { agree }\end{array}$ & Agree & Neutral & Disagree & $\begin{array}{c}\text { Strongly } \\
\text { Disagree }\end{array}$ \\
\hline $\begin{array}{l}\text { 17. Your teacher presents in a } \\
\text { friendly manner. }\end{array}$ & $36.09 \%$ & $52.31 \%$ & $9.52 \%$ & $1.19 \%$ & $0 \%$ \\
\hline $\begin{array}{l}\text { 18. Your teacher uses creative and } \\
\text { appropriate teaching methods. }\end{array}$ & $33.33 \%$ & $45.24 \%$ & $19.05 \%$ & $2.38 \%$ & $0 \%$ \\
\hline $\begin{array}{l}\text { 19. Your teacher helps you correct } \\
\text { your mistakes carefully. }\end{array}$ & $32.14 \%$ & $52.38 \%$ & $14.29 \%$ & $1.19 \%$ & $0 \%$ \\
\hline $\begin{array}{l}\text { 20. Your teacher provides } \\
\text { authentic and useful materials for } \\
\text { teaching }\end{array}$ & $25 \%$ & $47.63 \%$ & $23.8 \%$ & $2.38 \%$ & $1.19 \%$ \\
\hline $\begin{array}{l}21 . \text { Your teacher draws your } \\
\text { attention with enjoyable tasks. }\end{array}$ & $22.62 \%$ & $50 \%$ & $22.62 \%$ & $3.57 \%$ & $1.19 \%$ \\
\hline $\begin{array}{l}22 . \text { Your teacher is enthusiastic, } \\
\text { dedicated towards students. }\end{array}$ & $26.19 \%$ & $45.24 \%$ & $22.62 \%$ & $4.76 \%$ & $1.19 \%$ \\
\hline
\end{tabular}


Observing the above table, it was recognizable that teacher components affected students' motivation in multiform ways.

In statement 17, more than one-thirds of participants $(36.9 \%(31 / 84)$ "strongly agree" and 52.39\% (44/84) "agree") acknowledged that sentences with a teacher presenting in a friendly manner gave students more motivation. However, 8 respondents $(9.52 \%)$ did not take any side and there was one student, equivalent to $1.19 \%$, disagreeing with the statement.

For statement 18 's result, there were 2 students (2.38\%) giving objection and the ones staying in the middle were up to $19.05 \%$ (16/84). In contrast, 28 students, making up $(33.33 \%)$ and 38 remainders (45.24\%) strongly approved and approved the statement, successively. For that reason, the conclusion could be drawn that using creation and appropriate teaching method was necessary to draw students attention. Because it could make the lecture become interesting and therefore, it motivated students to learn in English classes.

About statement 19, findings also show that $26.19 \%$ of the participants $(27 / 84)$ strongly agreed in general that teacher's help in correcting mistakes carefully was motivating for them. With "agree" section, there was more than a half of participants ticking on it, making up 52.38\% (44/84). 12 students (14.29\%) did not choose any sides. In contrast, only $1.19 \%$ of the participants $(1 / 84)$ disagreed with this statement.

More than one-thirds of the participants selecting "agree" (47.63\%, 40/84) were motivated because their teacher provided authentic and useful materials for teaching in statement 20. In addition, 19 students had strong agreement, reaching $22.62 \%$ and there were 20 respondents (23.8\%) hesitating to answer. Just 2.38\% (2/84) and $1.19 \%(1 / 84)$ of the participants disapproved and strongly disapproved with this statement, respectively. Continuing with the last two statements, namely statement 21 and statement 22 . In the former, the proportion of the ones picking "strongly agree" was 22.62\% (19/84) and $50 . \%(42 / 84)$ was the percentage of students showing their agreement. Along with them, there were 19 participants $(22.62 \%)$ having no opinions and only 3 respondents $(3.57 \%)$ disagreed. Besides, only one student strongly approved with the statement. This manifested the fact that students could feel more excited if their teacher had enjoyable task instead of boring one. As for the latter, it could be deduced that approximately $75 \%$ of students $(26.19 \%(11 / 84)$ strongly agreed and $45.24 \%$ (31/84) agreed) confirmed that they had more power to study due to an enthusiastic and dedicated teacher. In addition, there were 19 freshmen (22.62\%) ticking on the column of "no idea" and 4 remainders $(4.76 \%)$ choosing "disagree". As a result of these two statements, it was easily visible that teachers' positive personalities and interesting exercises during lessons is one of the best strategies to increase students' motivation. 


\subsection{Extrinsic motivation related to parental factors}

Table 4: Extrinsic motivation related to parental factors

\begin{tabular}{|l|c|c|c|c|c|}
\hline $\begin{array}{l}\text { Parental factors are motivating } \\
\text { elements in learning English to } \\
\text { you because.... }\end{array}$ & $\begin{array}{c}\text { Strongly } \\
\text { agree }\end{array}$ & Agree & Neutral & Disagree & $\begin{array}{c}\text { Strongly } \\
\text { Disagree }\end{array}$ \\
\hline $\begin{array}{l}\text { 23. Your parents encourage you to } \\
\text { learn English as much as possible. }\end{array}$ & $27.38 \%$ & $54.76 \%$ & $16.67 \%$ & $1.19 \%$ & $0 \%$ \\
\hline $\begin{array}{l}\text { 24. Your parents say that English is } \\
\text { needed for your future job. }\end{array}$ & $32.14 \%$ & $50 \%$ & $13.1 \%$ & $2.38 \%$ & $2.38 \%$ \\
\hline $\begin{array}{l}\text { 25. Your parents will be proud of } \\
\text { you if you are good at English. }\end{array}$ & $42.86 \%$ & $42.86 \%$ & $14.28 \%$ & $0 \%$ & $0 \%$ \\
\hline $\begin{array}{l}\text { 26. Your parents always support } \\
\text { you when you have encountered } \\
\text { every difficulty in learning English. }\end{array}$ & $32.14 \%$ & $42.86 \%$ & $22.62 \%$ & $1.19 \%$ & $1.19 \%$ \\
\hline
\end{tabular}

Continuing with students' problems related to part of speech, table 4 consisted of 4 statements. First of all, for the statement 23, having particularly 23 students (2.38\%) utterly approved and 50/84 (54.76\%) of freshmen gave agreement toward the fact that their parents encouraged them to learn English as much as possible. The remaining was made up of $16.67 \%(14 / 84)$ and just $1.19 \%(1 / 84)$ of students having no idea and disapproving this statement, listed in succession.

The next one was statement 24 whose results revealed that approval was given by more than two-thirds of respondents. To be more specific, 32.14\% (27/84) gave strong agreement and 50\% (42/55) showed their concurrence. On the contrary, 11 students, corresponding to $13.1 \%$ stayed hesitated. The residual of disagreement and strong disagreement got the same result with $2.38 \%(2 / 84)$. Through the findings from this statement, it led to the conclusion that parents saying that English was needed for future jobs motivating their children to study this subject.

Now turning to the last two statements in the table, which are statement 25 and statement 26. In the former, no student disagreed with "Your parents will be proud of you if you are good at English". In contrast, there were 41 students (42.86\%) giving strong agreement, along with the concurrence of also 41 freshmen $(42.86 \%)$. As for the latter, the one giving disagreement and strong disagreement was only one student $(1.19 \%)$; however, the ones having no ideas were relatively more than with $19 / 84$ students $(22.62 \%)$ compared to $14.28 \%$ (12/84) in the previous statement. Besides, 30 participants $(32.14 \%)$ strongly agreed and 36 remainders (42.86\%) assented to the statement.

Thus, it could be noticed that parental factors played an important role in learning English and almost all of the students were more motivated when their parents supported and encouraged them to learn English. 


\section{Discussion}

The aim of this study was to investigate factors affecting motivation of English - majored freshmen towards learning English at Tay Do University. The study revealed that factors affected learner's motivation directly from intrinsic and extrinsic factors, in which learning environment, a good teacher and parents were external.

To begin with, it was a positive sign that participants indicated that they were motivated themselves towards learning English by intrinsic factors. More specifically, they showed their high agreement when they said that traveling, job opportunities and abilities of using English fluently were reasons for them. Almost of respondents wanted to get English competence for getting higher achievements. They realized that English played a vital role and they needed to enhance their English skills day by day.

Nextly, the present study showed that parental factors played an important role in learning English and almost all of the students were more motivated when their parents support and encourage them to learn English. Moreover, most of the students were more motivated when their parents stressed the importance of English for the future job.

For the teacher's factors, approximately $90 \%$ of the participating students admitted that they got more motivated when teachers used authentic, useful materials and had creative teaching methods related to why they were involved in an activity and its goal. Teachers' friendly behavior during lessons was one of the best strategies to increase students' motivation. Additionally, helping dedicatedly all students in the English lessons was important to create students' motivation at the highest possible level. Finally, regarding the in-classroom factors, most students seemed to be more motivated when they got to work with their active friends. Another important finding was that many of the participants were demotivated when the class was crowded, noisy and has heating problems because they wanted to study in a comfortable environment. Besides, students would be more motivated to study if they were free to give their opinions for contributing the lessons. Therefore, it was concluded that learning environment affected learners' motivation in learning English.

\section{Conclusions}

After conducting this research by analyzing the important information collected from freshmen at Tay Do University, the researcher finally found out that there were factors affecting motivation of English majored freshmen towards learning English at Tay Do University relating to intrinsic motivation, learning environment, parental elements and teacher components.

As indicated in chapter 4, students were motivated in learning English due to intrinsic factor (personal factor). They realized the importance of learning English and they had a desire to learn English (I am interested in learning English) to obtain the English proficiency. It could help them to get their dream jobs in the future and develop personal 
interests which required English competence such as traveling abroad, accessing to entertainment products in English.

For teacher components, it was found that teachers had influence on a students' motivation. A teacher with positive personalities, namely, kindness, creativity, enthusiasm, thoroughness in both teaching method and manner could attract students' attention. Thanks to that, teaching and learning could have a better result.

Nextly, learning environment was one of the factors that affected learners' motivation. Students could have inspiration to study well if they got to study with many active friends, feel comfortable and be free to express ideas with no fear. Besides, a well-equipped classroom with suitable light, temperature and sound would bring a secured feeling for students, so they were motivated to study better.

Finally, the given result proved that parents played a vital role in motivating their children for English learning. All of the learners have had some expectations from their parents while they are learning English. Therefore, supports, encouragement and precious advice by parents for learning English helped them to become motivated learners.

\section{Conflicts of interest statement}

The authors whose names are listed immediately below certify that they have no conflicts of interest, authorship, and disclosures in publication. They confirm that this work is original and has not been published elsewhere, nor is it currently under consideration for publication elsewhere.

\section{About the authors}

Thi Bao Dung Dang is currently a lecturer at Faculty of Linguistics and Literature, Tay Do University, Can Tho, Vietnam. She received her MA from Vitoria University, Australia. She has just completed her PhD program on comparative linguistics of Viet Nam National University Ho Chi Minh City, University of Social Sciences and Humanities (VNUHCM-USSH). Her research interests include linguistic features of Vietnamese and English political discourse. She has been teaching English for 20 years. She specializes in Cultures of English speaking countries, English for purposes and language skills.

Van Lanh Le is currently a lecturer at Faculty of Linguistics and Literature, Tay Do University, Can Tho, Vietnam. He received his MBA from Tay Do University and M.A from Can Tho University. He has been teaching English for 20 years. He specializes in Cultures of English speaking countries, English for purposes and language skills. At present, he is conducting some research on topics related to test-preparation teaching and collocations.

Tuong Vi Ha has just completed her BA program of English language of Faculty of Linguistics and Literature, Tay Do University, Can Tho, Vietnam. Her desire is to become a teacher of English. She is now preparing for her MA program to make her dream come true. 


\section{References}

\section{A. Books and Journals}

Aldridge, J. M., Dorman, J. P., \& Fraser, B. J. (2004). Use of multitrait - multimethod modeling to validate actual and preferred forms of the Technology Rich Outcomes - Focused Learning Environment Inventory (TROFLEI). Australian Journal of Educational and Developmental Psychology, 4, 110 - 125.

Alizadeh, M. (2016). The Impact of Motivation on English Language Learning. International Journal of Research in English Education, 1(1). 11-15.

Anjomshoa, L. and Sadighi, F. (2015). The Importance of Motivation in Second Language Acquisition. International Journal on Studies in English Language and Literature, 3(2). 126-137.

Arai, K. (2004). What 'demotivates' language learners?: Qualitative study on demotivational factors and learners' reactions. Bulletin of Toyo Gakuen University, $12,39-47$.

Bayraktar, H. V. (2015). Sınıf Yönetiminde Öğrenci Motivasyonu Ve Motivasyonu Etkileyen Etmenler/Student Motivation in Classroom Management and Factors That Affect Motivation. Turkish Studies International Periodical for The Languages, Literature and History of Turkish or Turkic, 10 (3), 1079-1100.

Bekleyen, N. (2011). Demotivating Factors in the EFL Environment. Paper presented at the 4th International Online Language Conference, Malaysia.

Bernaus, M. (1995). The role of motivation in learning English of English as a foreign language. Barcelona English Language and Literature Studies.

Bolkan, S., \& Goodboy, A. K. (2010). Transformational leadership in the classroom: The development and validation of the student intellectual stimulation scale. Communication Reports, 23, 91-105. doi:10.1080=08934215.2010.511399.

Brophy, J. (2004). Motivating Students to learn. New Jersey: Lawrence Erbaum Associates.

Bucholz, J. L., \& Sheffler, J. L. (2009). Creating a warm and inclusive classroom environment: Planning for all children to feel welcome. Electronic Journal for Inclusive Education, 2(4).

Retrieved from http://corescholar.libraries.wright.edu/cgi/viewcontent.cgi?article=1102\&co ntext=ejie.

Butler, Y. G. (2014). Parental Factors in Children's Motivation for Learning English: a case in China, Research papers in Education, 30(2),164-191.

Chiew Fen Ng and Poh Kiat Ng (2015). A Review of Intrinsic and Extrinsic Motivations of ESL Learners. International Journal of Languages, Literature and Linguistics, Vol. 1, No. 2.

Deci, E. \& Ryan, R. (2000). The "What" and "Why" of Goal Pursuits: Human Needs and the Self-Determination of Behaviour. Psychological Inquiry, 11, 227-268.

Deci, E. L., Koestner, R., \& Ryan, R. M. (2001). Extrinsic rewards and intrinsic motivation in education: Reconsidered once again. Review of Educational Research, 71, 1-27.

Dörnyei, Z. (2001). Motivational strategies in the language classroom. Cambridge: CUP. 
Dörnyei, Z. and Ushioda, E. (2011). Teaching and Researching Motivation. Harlow: Pearson Education Limited, 2(1). 137-139.

Eccles, J.S. and Harold, R. (1993). Parent - school involvement during the early adolescent years. The teachers college record, 94: 568-587

Ekiz, S. (2016). The factors affecting learner's motivation in English language education. Journal of foreign language education and technology, 1 (1).

Ekiz, S. and Kulmetov, Z. (2016). The Factors Affecting Learners' Motivation in English Language Education. Journal of Foreign Language Education and Technology, 1(1), 2533.

Emily, R. Lai (2011). Motivation: A Literature Review. Pearson Research Report.

Falout, J., \& Maruyama, M. (2004). A comparative study of proficiency and learner demotivation. The Language Teacher, 28, 3-9.

Fan, X. and Chen, M. (2001). Parental Involvement and Students' Academic Achievement: A Meta-Analysis. Educational Psychology Review, 3(1), 1-22.

Gardner, R. C. (1985). Social psychology and second language learning: The role of attitudes and motivation. London: Edward Arnold Publishers.

Garrett, S. (1995). America's Smallest Schools: Families. Vital Speeches of the Day, 61 (24), 742-749.

Good, T., \& Brophy, J. (1994). Looking in classrooms (6thed.). New York: Harper Collins.

Guthrie, J. T., \& McCann, A. D. (1997). Characteristics of classrooms that promote motivations and strategies for learning. In J. T. Guthrie \& W. Wigfield (Eds.), Reading engagement: Motivating readers through integrated instruction (pp. 128-148). Newark, DE: International Reading Association.

Hamidah A. R., Azizah R, Shah R. A. W., et al. (2017). Factors Affecting Motivation in Language Learning. International Journal of Information and Education Technology,7(7), 544-546.

Lucas, R. I., Pulido, D., Miraflores, E., Ignacio A., Tacay, M, \& Lao, J. (2010). A study on the intrinsic motivation factors in second language learning among selected freshman students. Philippine ESL Journal, 4, 3-23.

MacIntyre, P. D. (1999). Language anxiety: A review of the research for language Teachers. In Young, D. J. (Eds.). Affect in foreign language and second language learning. Boston, MA: McGraw-Hill, pp. 24-45.

Mendes, E. (2003). What empathy can do. Educational Leadership, 61(1), 56-59.

Meshkat, M. and Meskani, M. (2012). Demotivating factors in learning English: the case of Iran. 745-749.

Moskovsky, C., G., \& Alrabai, F. A. (2009). Intrinsic Motivation in Saudi Learners of English as a Foreign Language. The Open Applied Linguistics Journal, 21-10.

Oletić, A. (2014). Intrinsic and extrinsic motivation for learning English as a Foreign Language. ELTA Journal 2(2),23-38.

Pintrich, R. P. \& Linnenbrink, A. E. (2003). The role of self-efficacy beliefs in student engagement and learning in the classroom. Reading and writing quarterly,19(2).119137. 
Qin Zhang (2014). Assessing the effects of Instructor Enthusiasm on Classroom Engagement, learning Goal Orientation, and Academic self-efficacy. Journal Communication Teacher, vol. 28, p44-45.

Sakai , H., \& Kikuchi, K. (2009). An analysis of demotivators in the EFL classroom. System. $37,57-69$

San, N. (2018). A Study on Factors Affecting Students' Motivation in the English Language Classrooms. India's Higher Education Authority UGC Approved List of Journals Serial Number 49042, 18(4), 207-218.

Topalov, J. (2011). Motivacija u nastavi stranog jezika. Novi Sad: Prosveta.

Trong Tuan, L. (2012). An Empirical Research into EFL Learners' Motivation. Theory and Practice in Language Studies 2(3), 430-439.

Vallerand, R. J., L. G. Pelletier, M. R. Blais, N. M. Briere, C. Senecal, and E. F. Vallieres (1992). The Academic Motivation Scale: A measure of intrinsic, extrinsic and amotivation in education. Educational and Psychological Measurement, 52, no. 4: 1003-1017.

Weimer, M. (2009). Effective Teaching Strategies: Six Keys to Classroom Excellence. Faculty Focus-Higher Education Teaching Strategies from Magna Publications.

Young, D. J. (1999). Affect in foreign language and second language learning. Boston, MA: McGraw-Hill.

Yuko, G. (2014). Parental factors in children's motivation for learning English: a case in China. Journal research papers in education, vol.30, p.164-191.

\section{B. Internet}

Definition of motivation - Cambridge Dictionary. Retrieved March 9, 2020 from https://dictionary.cambridge.org/vi/dictionary/english/motivation

Definition of motivation - Boundless Psychology. Retrieved March 9, 2020 from https://courses.lumenlearning.com/teachereducation $\times 92 \times 1 /$ chapter/definingmotivation/

How People Learn: Brain, Mind, Experience, and School: Expanded Edition. Retrieved March 12, 2020 from https://www.nap.edu/read/24783/chapter/8

Huitt, W. (2001). Motivation to Learn: an Overview. Retrieved from http://chiron.valdosta.edu/whuitt/col/motivation/motivate.html.

Nuridin, W. (2019). The importance of motivation in language learning. ELF Magazine. Retrieved from https://www.eflmagazine.com/the-importance-of-motivation-inlanguage-learning/

Schmitz, T. (2012). Motivation - The Key to Success. Retrieved from https://www.conovercompany.com/motivation-the-key-to-success/.

Sibanda, T. S. (2015). Introduction to Motivation Presentation. Retrieved March 12, 2020 from

https://www.academia.edu/27557623/IntroductiontoMotivationPresentation. 
Thi Bao Dung Dang, Van Lanh Le, Tuong Vy Ha

FACTORS AFFECTING MOTIVATION OF ENGLISH-MAJORED STUDENTS TOWARDS

LEARNING ENGLISH AT A UNIVERSITY IN THE MEKONG DELTA, VIETNAM

Zambas, J. (2019). Why Motivation Is Important for Your Success and Happiness. Retrieved from https://www.careeraddict.com/why-motivation-is-important-forsuccess-and-happiness.

Creative Commons licensing terms

Authors will retain the copyright of their published articles agreeing that a Creative Commons Attribution 4.0 International License (CC BY 4.0) terms will be applied to their work. Under the terms of this license, no permission is required from the author(s) or publisher for members of the community to copy, distribute, transmit or adapt the article content, providing a proper, prominent and unambiguous attribution to the authors in a manner that makes clear that the materials are being reused under permission of a Creative Commons License. Views, opinions, and conclusions expressed in this research article are views, opinions and conclusions of the author(s). Open Access Publishing Group and European Journal of English Language Teaching shall not be responsible or answerable for any loss, damage or liability caused in relation to/arising out of conflict of interests, copyright violations and inappropriate or inaccurate use of any kind content related or integrated on the research work. All the published works are meeting the Open Access Publishing requirements and can be freely accessed, shared, modified, distributed and used in educational, commercial and non-commercial purposes under a Creative Commons Attribution 4.0 International License (CC BY 4.0). 